DePauw University

Scholarly and Creative Work from DePauw University

Summer 2006

\title{
Book Review: When Corporations Rule the World (second edition), The Post Corporate World: Life after Capitalism
}

Glen Kuecker

DePauw University, gkuecker@depauw.edu

Follow this and additional works at: https://scholarship.depauw.edu/hist_facpubs

Part of the Economic History Commons

\section{Recommended Citation}

Post-print used with permission of: "Book Review: When Corporations Rule the World (second edition), The Post Corporate World: Life after Capitalism" Review of Radical Political Economics. Vol. 38; No. 3 (Summer 2006): pp. 430-435. doi: 10.1177/0486613406291043 Copyright is held by the publisher. The published article may be accessed at: http://rrp.sagepub.com/content/38/3/430.full.pdf+html

This Article is brought to you for free and open access by the History at Scholarly and Creative Work from DePauw University. It has been accepted for inclusion in History Faculty publications by an authorized administrator of Scholarly and Creative Work from DePauw University. 
When Corporations Rule The World. David Korten. San Francisco and West Hartford, CT. Kumarian Press and Berrett-Koehler Publishers. Second Edition. 2001. 384 pp. $\$ 16.95$ (paperback).

The Post Corporate World: Life After Capitalism. David Korten. San Francisco and West Hartford, CT. Kumarian Press and Berrett-Koehler Publishers. 1999. 318 pp. $\$ 19.95$ (paperback). $\$ 27.95$ (hardcover).

Reviewed by Glen David Kuecker, DePauw University.

Before September $11^{\text {th }}$ it was not uncommon to see banners at globalization protests that read, "Read Korten's Post-Corporate World!" Nate Blakeslee (2000), writing for The Texas Observer, proclaimed Korten and the likes of Walden Bello (1999) "are quickly becoming the unlikely heroes of what appears to be a movement at the moment of coalescence in this country." Korten's status was partly earned by his cunning critique of Thomas Friedman, whose New York Times editorials ridiculed protestors, and whose book, Lexus and the Olive Tree (1999), celebrated globalization (Korten 1999a). A public intellectual, member of the "system" turned critic (PhD from Stanford, Harvard Business School professor, Ford Foundation and U.S. Aid for International Development officer), and visionary promoter of a world without capitalism, Korten's ideas appeal widely $(2001,12-19,383-384)$. Arguing "something has gone terribly wrong," he presents a powerful critique of corporate capitalism, showing how it undermines market economics and destroys the foundations of life on earth $(2001,28)$. Korten shows humanity is at a potentially catastrophic evolutionary tipping point. We live an illusion, unable or unwilling to see the coming calamity despite abundant warnings. Korten's message, however, is optimistic; the point of no return has yet to arrive. The course can be changed if 
people so decide. Escape depends on a culture shift, a spiritual awakening that affirms life over money. Explaining how change will happen, however, is Korten's shortcoming, as wishful thinking, simplistic understanding of social change, and faulty complexity theory permeate the analysis. Ultimately, the nightmare scenario of the post-September $11^{\text {th }}$ convergence of neoliberal economics and neoconservative politics in forming unrestrained empire demonstrates the weakness of Korten's critique of globalization. It is unable to respond to robust, unapologetic empire.

Korten's books are intended for a general audience. They are a valuable introduction to corporate power, capitalism's negative impact, and the depths of false consciousness. Readers unfamiliar with these topics will find his approach eye opening and informative. His clear presentation of alternatives counters the neoliberal's "no alternative" argument. These strengths make Korten valuable in the classroom. The two volumes compliment books critical of corporate globalization, such as Naomi Klein's (2002). Korten depends on secondary literature, weaving together a diverse range of thinking from economics to new age ecology. The synthesis is original, providing substance for academic specialists. Korten was among the first to articulate a critique of globalization, making his books important for understanding the anti-globalization movement.

Unlike other establishment members turned critics, such as Joeseph Stiglitz (2002), whose analysis of globalization is an internal squabble between the World Bank and the International Monetary Fund over who to blame for the catastrophic failures of free trade economics in the 1990s, Korten recognizes the deep flaws of corporate capitalism. When Corporations Rule the World presents Korten's thesis on corporations, defining them as the ill confronting humanity. It 
examines global problems, especially in the areas of environment, population, and inequality. The sequel, The Post Corporate World, advances Korten's solutions, or alternative directions we can choose to take. There is, however, a major analytical disjuncture in Korten's analysis. In When Corporations Rule the World he argues corporate power distorts the political economy, corrupting everything it contacts. In The Post Corporate World, however, Korten finds capitalism to be the evil. Capitalism perverts market economies, destroying them like a cancer. This shift is significant, because it moves critique and solution from a reformist approach to a radical proposition of a world without capitalism.

Korten's argument against corporations focuses on the destructive impact of externalized costs. It is based on his conviction that neoliberal economists have betrayed the ideas of Adam Smith and David Ricardo (2001, 81; 1999, 3939). They "maintain that the market turns unrestrained greed into socially optimal outcomes. Smith would be outraged by those who attribute this idea to him" (2001, 81). Korten continues, "Smith never suggested that government should not intervene to set and enforce minimum social, health, worker safety, and environmental standards in the common interest or to protect the poor and nature from the rich" $(2001,81)$. Instead of optimal outcomes, corporations distort the market by externalizing costs. "Market theory," Korten explains, "also specifies that for a market to allocate efficiently, the full costs of each product must be born by the producer and be included in the selling price" $(2001,82)$. By externalizing costs corporations extend their benefit and society's costs to a global level through a perversion of comparative advantage. "When capital is confined within the national borders of trading partners," Korten states, 
"it must flow to those industries in which its home country has a comparative advantage. When the economies are merged, capital flows to whatever locality offers the maximum opportunity to externalize costs through cash subsidies, tax breaks, substandard pay and working conditions, and lax environmental standards" $(2001,85)$. Corporations transcend national restraints upon the pursuit of profit and power. The result is a "race to the bottom" where corporations play nations off each other for the most advantageous terms of doing business. "As local settings are opened to the global economy, it becomes possible, and highly profitable, for a firm to take advantage of the differences between localities with regard to wages, market potential, employment standards, taxes, environmental regulations, local facilities, and human resources" $(2001,128)$.

Corporations, Korten explains, usurp power from people and the state. The argument borrows from William Greider (1992), and anticipates recent work on the changing nature of sovereignty. William Robinson (2004) and Michael Hardt and Antonio Negri (2000), for example, illustrate how transnational elites, institutions, and corporations deprive sovereignty from the state and the people. Power amalgamation is caused by corporate tendency to limit liability for their public consequences, and because they seek to reduce risk within the capitalist market. The result is a monopolistic propensity. The history of corporations is a battle to extend their rights in place of the public interest that reduces corporate accountability (2001, 59-63). As an alternative Korten advocates a strong, activist state -- what he calls "democratic pluralism" -- to counter corporate power. He defines democratic pluralism as "a system of governance based on a pragmatic, 
institutional balance among the forces of government, market, and civil society" $(2001,94)$.

Markets are not the source of the problem, according to Korten. Instead, "properly regulated markets are the most efficient way to allocate resources" $(2001,8)$. Korten thinks corporations distort and subvert the positive features of markets. In The Post Corporate World, he takes a radical step further: capitalism "is to a healthy market economy what cancer is to a healthy body" $(1999,15)$. Korten asserts, "I see no realistic prospect for the amicable coexistence of life and capitalism" $(1999,16)$. Korten offers five propositions, derived from his reading of Adam Smith, for how we should use markets to organize our economy. First, we need small firms instead of mega-corporations. "Efficiency of the market's self-organizing dynamic," Korten states, "is a consequence of small, locally owned enterprises competing in local markets." Second, we need complete information about all market factors, including accurate prices containing full production costs. Accurate prices also require the end of corporate welfare which finds the U. S. government providing $\$ 75$ billion in direct cash subsidies plus another $\$ 60$ billion in industry-specific tax breaks. Fourth, balanced international accounts are requisite to make comparative advantage work. Capital must "be nationally owned and remain within national borders." Finally, capital ought to be invested in production not speculation. Taken collectively, Korten's market ideas rest on Smith's notion of a self-regulating system $(1999,40-51)$. He does not explain, however, how small and local production will necessarily obviate the ills of capitalism.

Culture, especially mentalities integral to how people understand the world, is important for how Korten links arguments about markets with a vision 
of social change. Kenneth Boulding's (1968) "cowboys in a spaceship" is Korten's lead cultural metaphor. "Boulding suggested that our problem results from acting like cowboys on a limitless open frontier when in truth we inhabit a living spaceship with a finely balanced life-support system" $(2001,32)$.

Destructive consumption characterizes cowboy mentality; whereas, spaceship mentality features life preserving teamwork and conservation. "We must adjust ourselves to the principles of a life-centered spaceship economics," Korten asserts. "On our current course, we are at once plundering our planet and tearing apart the fabric of non-market social relationships that are the foundation of human civilization, a direct consequence of our misperception of the human relationship to natural systems" $(2001,5)$. Cowboy mentality yields the "growth illusion," a conviction "that economic growth is the foundation of human progress" $(2001,42)$. Cowboy mentality has the erroneous view that we can grow out of problems. Korten illustrates, however, growth is driven by industries depending on harmful "drawing down natural capital" (2001, 43). The growth illusion is most clearly manifest by our equating economic success with gross domestic product; it fails to account for externalized costs. Spaceship mentality, however, factors in all costs to growth such as resource depletion and pollution $(2001,46 ; 1999,69-73)$.

Cowboy mentality also generates false consciousness among the corporate elite, whom he compares to the "cloud minders" featured in a Star Trek episode $(2001,107)$. They are detached from everyday life of billions of people, but make decisions determining their fate. For carrying out mass destruction, corporate leaders are rewarded with immense compensation packages. Their extraordinary comfort and privilege means "the system shields those who take 
such actions from the costs of their decisions, which are borne by the system's weaker members" (2001, 118; 1999, 79-83). The illusion of wellbeing is reproduced by an elite consensus, one built and maintained by a combination of global financial institutions, politicians, academics, advertising, and the media. This consensus is maintained behind closed doors, rendering it anti-democratic (2001, 135-141). False consciousness penetrates deeply into the modern mentality through advertising. Korten estimates in 1989 corporations spent $\$ 120$ per person on marketing, while an American adult sees 21,000 commercials annually (2001, 150-151). With this type of assault, the culture of consumption is hegemonic, what Jackson Lears (1985) calls the "common sense" of everyday life.

Breaking away from cowboy mentality's common sense is Korten's path toward a world without corporate capitalism. He calls for "culture shift," a paradigm change to the spaceship mentality. It will happen when individuals become aware, and, to paraphrase Ghandi, become the change they wish to see in the world. They have left the world of the "modernists" and have entered the world of the "cultural creatives," terms Korten borrows from Paul Ray (1999, 214-218; Ray 1996). Cultural creatives approximate people who live by Thomas Berry's (1988) vision of human society organized in harmony with earth's ecological system. They prioritize family, community, environment, and global citizenship. Similar to individuals portrayed by Paul Loeb (1999), they take direct action in their community, implementing alternatives to corporate capitalism $(1999,225-242)$. Korten estimates that cultural creatives number in the millions. They are the "unsung heroes of a new era," and are "already hard at work constructing the building blocks of a post-corporate-post-capitalist 
civilization" (1999, 2-3). The cultural creatives are those who make markets into self-regulating systems.

Korten's use of complexity theory pulls the argument together. It coalesces Smith's self-regulating system to the life system alternative of the cultural creatives. His complex system is derived from a particular version of complexity theory, what Korten calls the "new biology," which embraces ideas like James Lovelock's Gaia thesis (1995). Mae-Won Ho, a "biologist interested in how the wisdom embodied in living systems might help us to create life friendly economic institutions," introduced Korten to complexity theory $(1999,8)$. Korten embraces Ho's argument, "we are in the midst of a basic paradigm shift in science, from the metaphor of the machine to the metaphor of the living organism." The new paradigm holds the "universe" to be "a self-organizing system engaged in the discovery and realization of its possibilities through a continuing process of transcendence" $(1999,12)$. Complexity theory provides a disturbing warning that modernity has generated a complex adaptive system that contains the seeds of its own inevitable destruction, but it also contains the means toward salvation. A world prioritizing life over money, Korten argues, is when humans change behavior to harmonize with the complex webs of life. Korten, however, does not provide specific explanation for how the metaphor of living organism translates into concrete forms of social, political, and economic organization.

Mark Taylor (2001) explains how new cultural paradigms emerge during the tipping points of systemic transformation. Korten's cultural creatives are the actors producing a new paradigm. He offers an encyclopedic list of ideas and programs they have enacted. These focus on establishing small and local 
markets regulated for the public good. They also focus on shifting sovereignty from transnational corporations, elites, and institutions to people. Steps include: simplify life; buy small and local; keep informed; invest in community business; reduce automobile dependence; fund change; create a community currency; community self-reliance; vote; form global networks; develop a municipal foreign policy (1999, 266-275).

Financial Times' editor Martin Wolf painstakingly debunks the arguments advanced by anti-globalizers (2004). These arguments, however, fail to consider the multiple, concrete alternatives outlined by Korten. They command careful evaluation by pundits, not neglect, dismissal, and belittling. While Korten makes a valuable contribution by showing there are in fact alternatives to corporate power, there are three significant problems with his vision.

First, Korten's use of complexity is overly optimistic. Thomas HomerDixon (2000) demonstrates how complex systems inevitably succumb to breakdown because gaps in technology prevent resolution of catastrohic problems. Even if Korten's cultural creatives survive the neoconservatives, their ability to fix the system's future problems is questionable. Second, while the cultural creatives' lifestyle may be revolutionary, their lives do not constitute the acts of revolution necessary for ending capitalism. Korten's army of cultural creatives may act locally and think globally, but such action is all too often disarticulated, uncoordinated, and not aimed at transforming relations of power. They do not constitute a movement with potential counter-hegemonic capacity. Their numbers are insignificant compared to the billions who steadfastly buy capitalism's illusion and willingly play by the rules. Thinking otherwise made the left vulnerable to the neoconservative assault after September $11^{\text {th }}$; the 
cultural creatives' non-existent response to the assault highlights the lack of political and strategic substance of Korten's vision of social change. New age wishful thinking is no match to Machiavellian neoconservatives.

Korten's complexity argument is also contradictory. He states that we have passed the threshold (2001, 34-35), but optimistically argues we can change course. This reasoning betrays the principles of complexity theory: once a system tips, it is no longer possible to change the tipped system (Clark 2002; Chase-Dunn and Hall 1997). Disturbing questions arise: If we have passed the threshold, are alternatives moot? Should we be discussing what happens to humanity once modernity's complex system collapses? What are the economics of living catastrophe? With global population approaching 7 billion but moving toward 9 billion, we need to question Korten's proposed alternatives. Small and local may best fit a world prior to the great transformations of modernity; there were only 1.5 billion people in 1850 . Can we re-scale and re-locate production while sustaining 7-9 billion people, or is Korten's world really one of 1.5 Billion? If we do not re-scale and re-locate, will demographic adjustment happen with catastrophic systemic collapse? József Borocz (2005) shows it is possible to redistribute resources without destroying productive systems. But, he argues, such a project is impossible because we lack institutions and political will for radical change. The means for Korten's desired paradigm shift do not exist, nor are the cultural creatives able to cause it in the face of neoliberal and neoconservative power. The consequences are dire. Borocz states, "to put it plainly" we face "an abyss of unforeseeable consequences concerning the survival of humankind." While his solutions may not be realistic, Korten provides a valuable contribution for glimpsing the abyss. 


\section{References}

Bello, W. 1999. Dark victory: The United States and global poverty. Second edition. Oakland: Institute for Food and Development Policy (Food First).

Berry, T. 1988. The dream of the earth. San Francisco: Sierra Club Books.

Blakeslee, N. 2000. How to tell you're in a movement. The Texas Observer, May $12,2000$.

Borocz, J. 2005. Redistributing global inequality: A thought experiment. Economic and Political Weekly, February 26, 2005: 886-892.

Boulding, K. 1968. The economics of the coming spaceship earth. In Environmental quality in a growing economy, edited by H. Jarrett, 3-14. Baltimore: The Johns Hopkins University Press.

Chase-Dunn, C., and T. Hall. 1997. Rise and demise: Comparing world-systems. Boulder, CO.: Westview Press.

Clark, R. 2002. Global awareness: Thinking systematically about the world. New York: Rowman and Littlefield.

Friedman, T. 1999. Lexus and the olive tree. New York: Farra, Straus and Giroux, Inc.

Grieder, W. 1992. Who will tell the people? The betrayal of American democracy. New York: Simon and Schuster.

Hardt, M., and A. Negri. 2000. Empire. Cambridge: Harvard University Press. Homer Dixon, T. 2000. The ingenuity gap. New York: Alfred A. Knopf. Klein, N. 2002. No logo. No space. No choices. No jobs. New York: Picador. Korten, D. 1999a. We are the capitalists. You will be assimilated. Resistance is futile. Review of Lexus and the olive tree, by T. Friedman. Tikkun 14: 71-76. 
Lears, J. 1985. The concept of cultural hegemony: Problems and possibilites. American Historical Review 90: 567-593.

Loeb, P. 1999. Soul of a citizen: Living with conviction in a cynical time. New York: St. Martin's Press.

Lovelock, J. 1995. Gaia: A new look at life on earth. Oxford: Oxford University Press.

Ray, P. 1996. The rise of integral culture. Noetic Sciences Review (Spring): 4-15.

Robinson, W. 2004. A theory of global capitalism: Production, class, and state in a transnational world. Baltimore: The Johns Hopkins University Press.

Stiglitz, J. 2002. Globalization and its discontents. New York: W. W. Norton.

Taylor, M. 2001. The moment of complexity: Emerging network culture. Chicago: University of Chicago Press.

Wolf, M. 2004. Why globalization works. New Haven: Yale University Press. 